Tabell 1 Vanlige funn i cerebrospinalvæske ved leptomeningeal metastasering, bakteriell meningitt og tuberkuløs meningitt. I enkelte tilfeller vil allikevel cerebrospinalvæske være negativ ved leptomeningeal metastasering. Antall celler kan variere betraktelig

$\begin{array}{llll} & \text { Celler } & \text { Protein } & \text { Glukose } \\ \text { Leptomeningeal metastasering } & \uparrow & \uparrow \uparrow & \downarrow \downarrow \downarrow \\ \text { Bakteriell meningitt } & \uparrow \uparrow \uparrow & \uparrow & \downarrow \\ \text { Tbc-meningitt } & \uparrow \uparrow & \uparrow \uparrow & \downarrow \downarrow\end{array}$

usikkert funn grunnet uegnet materiale. Svar på enda en dyrking og PCR, tatt dag 17 av Tbc i spinalvæske, var negativ. Toxoplasma gondii-PCR, nevronantistoff, anti-MAG og GM1 var alle negative.

Dag 21 fikk pasienten på nytt en høyresidig dilatert lysstiv pupill og redusert bevissthet. CT caput ga holdepunkter for økende hjerneødem. Tuberkulostatika ble seponert dag 24. Pasienten ble gradvis mer redusert og fikk palliativ behandling. Han døde dag 32 uten diagnose.

Pasienten hadde initialt et spinalt syndrom, men sykdommen affiserte etter hvert hele nevroaksen. Til tross for klare nevrologiske utfall og funn var radiologisk utredning negativ. Autopsi var nødvendig.

Makroskopisk obduksjon viste arraktig fibrose i høyre lunge (fig 4a). I undersøkelse av ryggmarg, og spesielt cauda equina, var det upåfallende funn (fig 5a) og det ble gjort en kartografisk undersøkelse for detaljert histologisk kartlegging.

Først ved grundig histologisk undersøkelse fant man et lavt differensiert adenokarsinom $i$ høyre lunge, forenlig med et bronkioalveolært karsinom (fig $5 \mathrm{a}$ ) med diffus metastatisk meningeal karsinomatose i form av mikroskopisk spredning til spinale og cerebrale nerverøtter (fig 4b) og arachnoidea. Som bifunn fant man metastase til binyre. Immunhistokjemisk undersøkelse viste samme profil for tumorceller i lunge og sentralnervesystemet.

\section{Diskusjon}

Leptomeningeal metastasering forekommer hos om lag $5 \%$ av kreftpasienter i autopsi- studier (1). De vanligste forårsakende solide tumorer er brystkreft, lungekreft og melanom, men også lymfomer og leukemier kan danne svulster i meningene (1-4). Adenokarsinom er den vanligste histologitypen ved meningeal karsinomatose, men også småcellet lungekreft forekommer hyppig (1-3). De maligne cellene kan spres til cerebrospinalvæsken på flere måter - det kan være hematogen spredning til araknoidalkar eller (antakelig mindre vanlig) plexus choroideus eller direkte innvekst fra skjelett- og hjernemetastaser.

Multifokale funn fra sentralnervesystemet er et kjennetegn ved leptomeningeal metastasering. Cerebrospinalvæskevolumet er om lag $150 \mathrm{ml}$, og per døgn produseres det rundt $500 \mathrm{ml}$, noe som medfører et stort spredningspotensial når cerebrospinalvæskerommet først er nådd av maligne celler. Dette forklarer multifokalitet av symptomer og funn som kan utvikles over kort tid. Ved kjent primærtumor og multifokale nevrologiske utfall må man mistenke leptomeningeal metastasering. Utredningen bør da være MR med kontrast av de symptomatiske områdene før spinalpunksjon for ikke å få iatrogen oppladning på MR som følge av spinalpunksjonen (3). Ved kjent primærtumor og åpenbare funn på $\mathrm{MR}$ kan spinalpunksjon utelates (3). Ved manglende primærtumor, men multifokale nevrologiske utfall uten annen kjent årsak må leptomeningeal metastasering være en differensialdiagnose. Her bør det gjøres både MR og spinalpunksjon. Sistnevnte bør ved negativt funn gjentas minst to ganger, og det bør tas minst $10 \mathrm{ml}$ væske for å øke sensitiviteten betraktelig $(3,5)$. Lavt glukosenivå i cerebrospinalvæske er et typisk funn. Øvrige vanlige funn ved spinal- punksjon er åpningstrykk $>16 \mathrm{~cm} \mathrm{H}_{2} \mathrm{O}$, mild pleocytose, forhøyet proteinnivå, og ved malignt melanom kan det foreligge xantokromi (3) (tab 1).

Ved negativ cytologisk prøve kan måling av tumormarkører være diagnostisk nyttig. En høyere konsentrasjon av tumormarkører i cerebrospinalvæske enn i serum gir sterk mistanke om leptomeningeal metastasering. Både spesifikke (f.eks. MART-1 og MAGE3 ved malignt melanom) og uspesifikke (f.eks. LDH-isoenzymer) tumormarkører kan benyttes. Selv om diagnosen leptomeningeal metastasering kan være svært vanskelig å stille når det ikke er kjent kreftsykdom, er det uvanlig at gjentatte radiologiske og cytologiske undersøkelser ikke gir diagnosen, slik tilfellet var hos vår pasient.

\section{Kristin Lif Breivik}

kristin.lif.breivik@helse-forde.no

Nevrologisk avdeling

Sentralsjukehuset i Sogn og Fjordane 6807 Førde

\section{Ricardo Laurin}

Rolf Steen

Patologisk avdeling

\section{Karl Bjørnar Alstadhaug}

Nevrologisk avdeling

Nordlandssykehuset

Bodø

\section{Oppgitte interessekonflikter: Ingen}

\section{Litteratur}

1. Grossman SA, Krabak MJ. Leptomeningeal carcinomatosis. Cancer Treat Rev 1999; 25: 103-19.

2. Pentheroudakis G, Pavlidis N. Management of leptomeningeal malignancy. Expert Opin Pharmacother 2005; 6: 1115-25

3. Demopoulos A. Leptomeningeal metastases. Curr Neurol Neurosci Rep 2004; 4: 196-204.

4. Sulim S, Høyer M. Meningeal karcinomatose. Ugeskr Læger 2005; 167: 3481-4.

5. Glantz MJ, Cole BF, Glantz LK et al. Cerebrospinal fluid cytology in patients with cancer. Minimizing false-negative results. Cancer 1998; 82: 733-9.

Manuskriptet ble mottatt 12.2. 2008 og godkjent 12.3. 2009. Medisinsk redaktør Odd Terje Brustugun.

\title{
Ryggsmerter og multifokale symptomer fra nervesystemet
}

Breivik og medarbeidere beskriver en pasient med nyoppståtte og progredierende ryggsmerter. Hos eldre er dette et alarmsymptom som alltid bør vekke mistanke om kreftsykdom. Leptomeningeal spredning som debutsymptom ved en okkult cancer er relativt uvanlig, som regel har pasienten kjent kreftsykdom fra tidligere. Ved mistanke om leptomeningeale metastaser er det nødvendig med kartlegging av hele nevroaksen, ikke bare av de symptomgivende områdene. Normal MR-undersøkelse er imidlertid ikke helt uvanlig, særlig tidlig i forløpet (1). I typiske tilfeller ses leptomeningealt kontrastopptak over konveksitetene, i basalsisterner og langs ventrikkel- veggene samt intradurale ekstramedullære kontrastoppladende noduler spinalt, særlig i cauda equina (1).

Pasientens primærsvulst var også vanskelig å påvise. Ved sterk mistanke om kreft og manglende funn ved konvensjonelle radiologiske undersøkelser kan PET-undersøkelse med fluorodeoksyglukose være indi- 
sert. PET har høyere sensitivitet enn CT-undersøkelse ved små svulster, spesielt ved lokalisasjon i lungeparenkym og mediastinum, og kan også differensiere mellom lungefibrose og malignitet (2).

Majoriteten av pasientene med leptomeningeal spredning har disseminerte symptomer, særlig meningeale irritasjonsfenomener som hodepine og bevissthetsendring, hjernenerveutfall og spinale utfall i form av radikulopati, myelopati eller cauda equinasymptomer (1).

Det subakutte, raskt progredierende forløpet med multifokale symptomer bør også gi mistanke om paraneoplastisk sykdom, spesielt hos en røyker, fordi småcellet lungekreft er den vanligste årsaken til slike syndromer (3). Funn av polynevropati ved nevrografi kan styrke denne mistanken. I dette tilfellet var nevronantistoffene negative, men det utelukker ikke diagnosen. Derimot er lavt glukosenivå i spinalvæsken atypisk for paraneoplastiske tilstander. Kasuistikken gir en nyttig påminnelse om at dette funnet ikke er spesifikt for bakteriell infeksjon. Opptil $60 \%$ av pasientene med leptomeningeal spredning har lavt nivå av glukose i spi- nalvæsken - enten fordi glukose metaboliseres i de maligne cellene eller fordi tumorvekst nedsetter den frie passasjen av glukose over blod-hjerne-barrieren (4). Påfallende høyt proteinnivå i spinalvæsken, som kan forårsake spinalt blokk eller obstruktiv hydrocephalus, bør også gi mistanke om leptomeningeal tumorvekst. Cytologisk undersøkelse av spinalvæsken kan imidlertid bare påvise maligne celler i halvparten av tilfellene med leptomeningeale metastaser, og man bør eventuelt gjenta spinalpunksjonen for å $ø$ ke sensitiviteten (1).

Obduksjonsstudier har vist at $20-40 \%$ av alle som rammes av kreft har spredning til nervesystemet, men ofte dør pasienten av systemisk kreftsykdom før debut av nevrologiske symptomer. Det kan tenkes at dette er $\mathrm{i}$ endring. Når effektiv kreftbehandling fører til forlenget overlevelse, kan nervesystemet fungere som et «tilfluktssted» for metastaserende kreftceller, fordi mange cytostatika i liten grad passerer blod-hjerne-barrieren. I tillegg øker forekomsten av småcellet lungekreft og brystkreft, de kreftformene som også hyppigst gir leptomeningeal spredning (1). Ved progredierende sym- ptomer fra flere nivåer i nervesystemet bør denne diagnosen derfor alltid huskes - spesielt ved kjent kreftsykdom, men også ellers.

\section{Anette Storstein}

astt@helse-bergen.no

Nevrologisk avdeling

Haukeland universitetssykehus

Oppgitte interessekonflikter: Ingen

\section{Litteratur}

1. Gleissner B, Chamberlain MC. Neoplastic meningitis. Lancet Neurol 2006; 5: 443-52.

2. Ung YC, Maziak DE, Vanderveen JA et al. ${ }^{18}$ Fluorodeoksyglucose positron emission tomography in the diagnosis and staging of lung cancer: a systematic review. J Natl Cancer Inst 2007; 99: 1753-67.

3. Storstein A, Vedeler C. Paraneoplastiske nevrologiske syndromer. Tidskr Nor Legeforen 2009; 129 : $524-8$

4. Bruna J, González L, Miró J et al. Leptomenigeal carcinomatosis: prognostic features of clinical and cerebrospinal features. Cancer 2009. 115: 381 -9.

Manuskriptet ble mottatt 1.4. 2009 og godkjent 3.4. 2009. Medisinsk redaktør Odd Terje Brustugun. 